\title{
The Influence of the Project Team Efficacy and Organizational Factors on the Success of Mining Project Management
}

\author{
Arturo Rodolfo Saenz Arteaga* \\ Jhony Ostos Mariño** \\ Kerstin Bremser ${ }^{\star * *}$
}

Fecha de recibido: 27 de febrero de 2019

Fecha de aprobado: 9 de enero de 2020

Para citar: Saenz Arteaga, A. R., Ostos Mariño, J., \& Bremser, K. (2020). The influence of the project team efficacy and organizational factors on the success of mining project management. Revista Universidad \& Empresa, 22(39), 1-24. https://doi.org/10.12804/

Abstract

revistas.urosario.edu.co/empresa/a.7721

Some authors have proposed that project team efficacy influences the success of project management; however, this relationship has not been well investigated. The objectives of this study are to analyze the relationship between project team efficacy and the success of project management and to examine three moderator variables (task uncertainty, task interdependence, and chaos effect) in the relationship between them. This study was based on a sample of 52 mining work teams. The suggested hypotheses were confirmed, there is an influential relationship between project team efficacy and the success of mining project management, as well as the significance of the moderate variables.

Keywords: Team efficacy; project management; task uncertainty; task interdependence; chaos.

\footnotetext{
* Profesor a tiempo completo en Universidad ESAN. Investigador en el área de administración y finanzas con interés en Proyectos Mineros e Industriales. E-mail: asaenz@esan.edu.pe

** Profesor asociado en Universidad ESAN. Investigador en Teoría Organizacional y Administración de Negocios Estratégicos. E-mail: jostos@esan.edu.pe

*** Professor of International Business at the Pforzheim University of Technology. E-mail: Kerstin.bremser@hs-pforzheim.de
} 


\section{La influencia de la eficacia del equipo del proyecto y los factores organizativos en el éxito de la gestión del proyecto minero}

\section{Resumen}

Algunos autores han propuesto que la eficacia del equipo del proyecto influye en el éxito de la gestión del proyecto. Sin embargo, esta relación no ha sido bien investigada. Los objetivos de este estudio fueron analizar la relación entre la eficacia del equipo del proyecto y el éxito de la gestión del proyecto y examinar tres variables moderadoras (incertidumbre de la tarea, interdependencia de la tarea y efecto de caos) y la relación entre estas. El estudio se basó en una muestra de 52 equipos de trabajo minero. Se confirmaron las hipótesis sugeridas, existe una relación influyente entre la eficacia del equipo del proyecto y el éxito de la gestión del proyecto minero, así como la importancia de las variables moderadas.

Palabras clave: eficacia de equipo; administración de proyectos; incertidumbre de la tarea; interdependencia de la tarea; caos.

\section{A influência da eficácia da equipe do projeto e os fatores organizativos no sucesso da gestão do projeto de mineração}

\section{Resumo}

Alguns autores têm proposto que a eficácia da equipe do projeto influi no sucesso da gestão do projeto; no entanto, esta relação não tem sido bem pesquisada. O objetivo deste estudo é analisar a relação entre a eficácia da equipe do projeto e o sucesso da gestão do projeto e examinar três variáveis moderadoras (incerteza da tarefa, interdependência da tarefa e efeito de caos) na relação entre estas variáveis. Este estudo se baseou em uma amostra de 52 equipes de trabalho mineiro e confirmaram-se as hipóteses sugeridas, existe uma relação influente entre a eficácia da equipe do projeto e o sucesso da gestão do projeto de mineração, assim como a importância das variáveis moderadas.

Palavras-chave: eficácia de equipe; gestão de projetos; incerteza da tarefa; interdependência da tarefa; caos.

\section{Introduction}

Projects recently became considered a fundamental element to achieve strategic objectives in an organization (Blasco, 2001), and since then, project success has become the most studied issue within the field of project management (Shenhar \& Dvir, 2007). In reference to project success, maturity models (Jugdev \& Thomas, 2002 ; Farrel \& Gallagher, 2015), fuzzy logic (Liberatore, 2002), dynamic simulation (Doloi \& Jaafari, 2002), teamwork (Loo, 2002), decision making (McCray, Purvis, \& McCray, 2002), and even the concept of project success itself as a deliverable (Pennypacker \& Grant, 2003) have been the principle areas 
of investigation in the last decade, and these studies have generated new knowledge based on previously established models (Bredillet, 2008).

Although these models were developed to achieve project success, institutions such as e-Goverment for Development Exchange (eGov4Dev), The Treasury Board of Canada Secretariat, and The Standish Group's Chaos Report (2015) gather data from projects across a variety of industries that have reported that currently project success only reaches 28 or $30 \%$, a low value identified early by Herzog (2001) and that does not seem to improve over time (Rolfe, Segal, \& Cicmil, 2016). Adding to this, the fact that many projects developed with complex organizational structures and the best resources in time, cost, and good work teams do not guarantee success, whereas other projects with fewer resources and structures do succeed. Thus, there is a difficult state of affairs that is not explained well with current models (Olaniran et al., 2015).

With regards to the projects' low success value, early studies by Herzog (2001) indicated that the principal reason for this could be the insufficient interrelation with collaborative work, such as lack of confidence among team members who share responsibility for the project's success. In that context, Kendra and Taplin (2004) indicated that these lightweight conjectures need to be investigated more deeply to refute or accept the interrelation between project managers, project teams, methodology (processes), and the measurement systems that lead to success. Conversely, regarding the difficulty in explaining the results, early studies by Singh and Singh (2002) have conjectured that even though there may be an interrelation between managers, teams, methodologies, and measuring systems, the fact is that to date, their relationship cannot be explained clearly because even with a good manager and a good team, a project destined for success can still end in failure. Similarly, referring to the difficulty in explaining the results, Singh and Singh (2002) studies support the investigation of Parker and Stacey (1996), who indicated that the difficulty in explaining project success could be better understood using complexity theory.

Our motivation for researching the success of project management was born from this context, due to the scarcity of studies on this topic (Herzog, 2001; Kendra \& Taplin, 2004), which commands more relevance precisely because current models cannot explain why projects continue to fail. 
Although project management still lacks a convincing theory or even a central research paradigm (Shenhar \& Dvir, 2007), the study of the success of project management does take into account empirical generalizations, pseudo-theories, and related theories about projects, which provide primary information to formulate a study model. Empirical generalizations about projects refer to Blasco's (2001) studies, which consider projects as evolutionary/ cognitive systems that maintain a constant relationship with their team members. Related theories, such as organizational theory, restructuring theory, and complexity theory, offer new conjectures supported by mathematical analysis. In the first one, the theory of group behavior has been tested in traditional organizations (то); using epistemological parallelism, this can be extended for testing in project organizations (PO).

Due to the lack of formal academic writing to date about project management and the success of project management in po contexts, we begin our investigation with a theoretical framework that is common to TO, so that we can conjecture relevant variables and abstract them to PO, with the objective of responding to Bredillet's (2008) question of why project success is so elusive.

For this same reason, we base our investigation on previous studies of group efficacy, the achievement of objectives, and the group moderator factors that were applied in To, to then associate them with PO, taking an epistemological parallelism as a reference. In the success of project management, Loo (2002) found a possible relationship between project team efficacy and the success of project management, so these variables were taken into account for this study, along with additional moderator variables studied in group theory. In the same way, we added a dynamic moderator variable (chaos effect) obtained through CPI (Cost Performance Index) and SPI (Schedule Performance Index) values.

Consequently, the objectives of this study are to analyze the relationship between project team efficacy and the success of project management (productivity, customer service, quality) based on Gibson's (1999) group model and to examine moderator variables in relation to them. The analysis of the moderator variables took into account one dynamic moderator variable (chaos effect) and two traditional moderator variables according to Gibson's (1999) group model (task uncertainty, task interdependence). This study is significant, first, because it explores a new study model where "team" instead of "group" is considered a relevant variable for understanding the success of project teams, and, second, 
because the findings will improve the performance of organizations that depend on the success of project management.

In accordance with the requirements for research and with the objectives of study, the following research questions were put forward:

1. What is the relationship between project team efficacy and the success of project management?

2. To what degree do the organizational variables (traditional and dynamic) moderate the predictive power of project team efficacy on the success of project management?

\section{Theory and Hypothesis}

\subsection{Success of Project Management}

In project theory, organizations are dependent on success, but what is unclear is whether they are dependent on the success of the project or on the success of the project management (Shenhar \& Dvir, 2007). What is clear is that the quantification of the success of the projects starts with the identification and subsequent extraction of the deviations that are presented in the documentation of the same projects (Heravi \& Gholami, 2018).

There are diverse concepts regarding the success of projects but determining when a project is successful is a complex matter. Lavagnon (2009) indicates that a project can comply with the objectives of budget and time but can be either considered a success or a failure. There are other cases in which poorly managed projects, nevertheless, give good results, or vice versa; thus, why can the project be considered a failure if in the end the product is good? To rate the success of a project, one must be clear about the type of success being considered, whether the success of the project (products) or the success of the project management. 
The concept of project success is difficult to define (Lavagnon, 2009; Shenhar \& Dvir, 2007). To date, there is still no clear explanation of what the success/failure of a project means (Lavagnon, 2009). Project success has been considered to be the capacity to adjust to the restrictions imposed on a project, such as time, cost, and quality; this precise triangle of restrictions acts as a sufficient structure to define the success of a project (Westerveld, 2003). What is dichotomic in this definition is that many projects that are delivered within the time, cost, and quality parameters can still be considered failures (Shenhar et al., 2005), while other projects that exceed the restrictions of time, cost, and quality can be considered successes (Pinto \& Slevin, 1988).

This apparent paradox is not new and was identified early by De Witt (1988) who suggested the distinction between the success of a project and the success of the project management. With respect to project management, success is an ambiguous and multidimensional concept, which definition is limited to specific contexts (Shenhar \& Dvir, 2007). Authors such as Pinto and Slevin (1988), Shenhar and Dvir (2007), and Lavagnon (2009) suggest that few concepts in project management have been explained in the literature and that, to date, researchers have not been able to reach a consensus on the definitions. Researchers, implicitly or explicitly, discuss project success taking into account the success of project management or the management of successful projects (Lavagnon, 2009).

In accordance with the above, in this study, we take as the study variable the success of project management, which definition goes beyond the traditional restrictions of the project, such as time, cost, and quality, finding a new perspective for evaluation that considers productivity, customer service (Khang \& Moe, 2008), and quality (Mason \& Griffin, 2005) as new restriction factors to define the success of the project management.

\subsection{Project Team Efficacy}

Due to their ability to more effectively respond to the dynamic and complex environments faced by organizations today, work teams have become increasingly prevalent in the past two decades (Mathieu et al., 2008).

Gibson, Randel, and Earley (2000) affirmed that the achievement of the strategic objectives of the work groups is a well-studied topic unlike project teams; in project man- 
agement, the teams are more relevant than groups. On this topic, Lavagnon (2009) holds that a work group is not the same as a work team. A work group is a set of people who perform similar tasks, have the same boss, do the same type of work, respond individually, and do not depend on their coworkers' work; however, a work team corresponds to work conducted together, in which each member has a specific ability, each one performs part of the project, and whose tasks are simultaneously complementary and interdependent. Coordination is necessary for the team, so common performance standards must be established (e.g., rate of response, efficacy, precision, and dedication).

According to Gibson (1999), group efficacy in to is the belief in the capacity to effectively obtain a result; this concept is in accordance with what Lindsley, Brass, and Thomas (1995) indicated. Efficacy can be measured using interviews and observational and self-reporting techniques, with great statistical significance. Therefore, this concept will be taken into account in the present study. In many cases, the level of group efficacy varies even between groups that appear to have the same abilities, capacities, and resources (Campion, Medsker, \& Higgs, 1993; Earley, 1993). Given that projects can be classified into operative/ strategic and external/internal (Shenhar \& Dvir, 2007), in accordance with the findings of Gibson (1999), a parallel can be drawn between the level of group efficacy and project teams; that is, each project team will have different efficacy levels, even though they have the same training and resources.

The relationship at the group level between group efficacy and achieving the strategic objective is modest, complex, and apparently moderated by other factors in the workplace (Campion et al., 1993; Earley, 1993). Alternatively, Campion et al. (1993) and Earley (1993) proposed that the level of group efficacy is related to how much effort the group exerts, and this effort is a determinant in the group's achievement of the strategic goal -a factor as yet unconsidered in project management. For this reason, the achievement of the strategic goal should be grounded in analyzing constructs that involve groups, because organization grew out of the human need to cooperate and reach group and personal goals due to human physical, biological, psychological, and social limitations, and managerial abilities group (Carpim, de Souza, \& Novaski, 2015). 


\subsection{Project Team Efficacy and the Success of Project Management}

Group efficacy and its relationship to achieving the objectives of a traditional organization have been investigated by various authors. In accordance with the writings of Lindsley et al. (1995) and Gibson (1999), group efficacy is related to achieving objectives, but this relationship is limited to specific cases within the organization; thus, it is not possible to generalize its applicability to project organizations due to the difference between To and po with regards to their temporal nature. po require their own tools, techniques, and conceptual analysis. In this regard, Lavagnon (2009) holds that project organization is a professional, scientific specialization limited by the temporal, innovative, unique, and multidisciplinary nature of projects. However, with respect to group behavior, De Witt (1988) holds that groups from a traditional organization can be replicated in po, given that it is a branch of the administration; therefore, the dichotomy with regard to the behavior of groups and of project teams needs to be explored.

The positive relationship between the variables of group efficacy and achieving objectives has been relevant in To due to the collective behavior of the group that plays an important role in the achievement of objectives; nevertheless, high group efficacy does not necessarily correlate with high objective achievement (Gibson, 1999). Therefore, project teams, as part of the human resources of project organizations, have an important place in the achievement of strategic objectives, which can also be termed project success (Shenhar \& Dvir, 2007).

Alternatively, although not as expected, the studies of Rakestraw (2014) showed that feedback relative to success - in this case, a lack of success - does not appear to have had an effect on team performance, something that differs from what has been established by Amoako-Gyampah, Meredith, and White (2018) in their "top management commitment causal map," where a new relationship between team performance and project success is shown.

Those teams that were unsuccessful at the beginning were the most successful at the end, because they improved their teams' functioning. Conversely, the successful teams 
failed, because they may have felt that there was nothing to learn or improve after experiencing success.

Given the aforementioned findings, the following hypothesis raised:

H1: The greater the project team efficacy is, the lower the success of project management.

However, earlier studies have demonstrated that in the case of groups, this relationship is moderated by traditional factors (Gibson, 1999) and may even be affected by unknown dynamic and complex factors (Singh \& Singh, 2002) if it is conjectured in project organization.

On the other hand, in project management research this could include types of interdependencies between team projects and perceived project efficacy data derived from organizational charts and performance outcomes such as meeting cost targets of project units (Steen et al., 2018).

\subsection{Chaos Effect, Task Uncertainty, and Task Interdependence as Moderate Variables}

\subsubsection{Chaos effect}

Singh and Singh (2002) indicated that when individuals begin to reason with a basis in a shared experience and see their lives or the world around them in the same way, a science develops. According to this and in accordance with the studies of Singh and Singh (2002), Parker and Stacey (1996), and findings of Parkinson (1957), new relationships are constructed that consider time, cost, and quantity of resources as relative variables that allow for a new moderator variable.

In accordance with the reasoning of Singh and Singh (2002), and taking into account complexity theory, the chaos effect variable is finally building as rates between earned value (schedule and cost) and planned value, and it is compared with initial values according to Henderson and Zwikael (2008). 
We do this because the correlation between stabilized and cumulative values of CPI and SPI (Christensen \& Templin, 2002) cannot be generalized and it only applies to commercial sector projects (Henderson \& Zwikael, 2008).

This new moderator variable will be introduced to project management taking into account that the chaos effect has a chaotic, non-linear behavior that regulates the relationship between team efficacy and the success of project management.

Given all the foregoing, the following hypothesis raised:

H2: In a project team, the chaos effect negatively moderates the relationship between project team efficacy and the success of project management, such that the greater the chaos is, the lower the success of project management.

\subsubsection{Task Uncertainty}

In accordance with the study of Gibson (1999), when the information about the task is clear and with low task uncertainty, groups can be confident that certain strategies will lead to the achievement of the strategic objective; this confidence forces the group to believe that project group efficacy is related to the success of project management. However, when there are conditions of high uncertainty, the group is not necessarily sure of achieving an effective level of success, which signifies that in this circumstance, there is no relationship between project team efficacy and the success of project management.

The groups with high efficacy are convinced that they will have an effective performance, but due to the ambiguity of the task, their chances of reaching the objective are very low. In an organization, the groups with a low level of efficacy can sometimes have a high performance and sometimes a low performance due to the task uncertainty. Thus, under conditions of high task uncertainty, there is no guarantee of a relationship between group efficacy and the success of project management. Therefore, task uncertainty is a variable that must be explored to understand how much it regulates the relationship between project team efficacy and the success of project management. 
Given the aforementioned findings, the following hypothesis raised:

H3: The level of task uncertainty for the project team positively moderates the relationship between project team efficacy and the success of project management, such that the greater the task uncertainty for the project team is, the greater the success of project management will be.

\subsubsection{Task Interdependence}

Task interdependence is a structural characteristic of work; the instructions that define a task create a level of interdependence that influences the interaction of the members when they execute the tasks. When task interdependence is low, communication occurs less frequently, and the necessary knowledge to complete the task is not necessarily shared and integrated with the group (Wageman, 1995).

Gibson (1999) and Goodman, Ravlin, and Schminke (1990) indicated that the characteristics of the task can potentially moderate the beliefs of group efficacy because they relate to the type of knowledge the group possesses to perform adequately and to the degree to which the members are able to combine and integrate each individual's knowledge. However, several authors, such as Shenhar and Dvir (2007) and Turner and Müller (2003), note that the characteristics of the task are associated with project groups through their typologies. In this area, task characteristics are presented as a moderator variable of the relationship between project team efficacy and the success of project management, so their regulatory capacity should be tested.

Given the aforementioned data, the following hypothesis raised:

H4: The level of task interdependence for the project team negatively moderates the relationship between project team efficacy and the success of project management, such that when the interdependence is high and the efficacy low, the success is bigh; conversely, when the interdependence is low and the efficacy high, the success is low. 


\section{Methodology}

\subsection{Study Model}

A literature review allowed us to identify the set of variables related to the success of project management. The studies on team works of $\mathrm{Hu}$ and Liden (2015), project management of Singh and Singh (2002), and Gibson (1999) on organizational management demonstrated the presence of distinct transversal variables that demarcate this study (figure 1); thus, a new study model is proposed that considers the success of project management as the dependent variable and project team efficacy as the independent one.

At the same time, we propose three moderator variables that affect the relationship between these two variables, two of which correspond to the traditional moderator variables (task uncertainty, task interdependence), and one dynamic moderator variable (chaos effect).

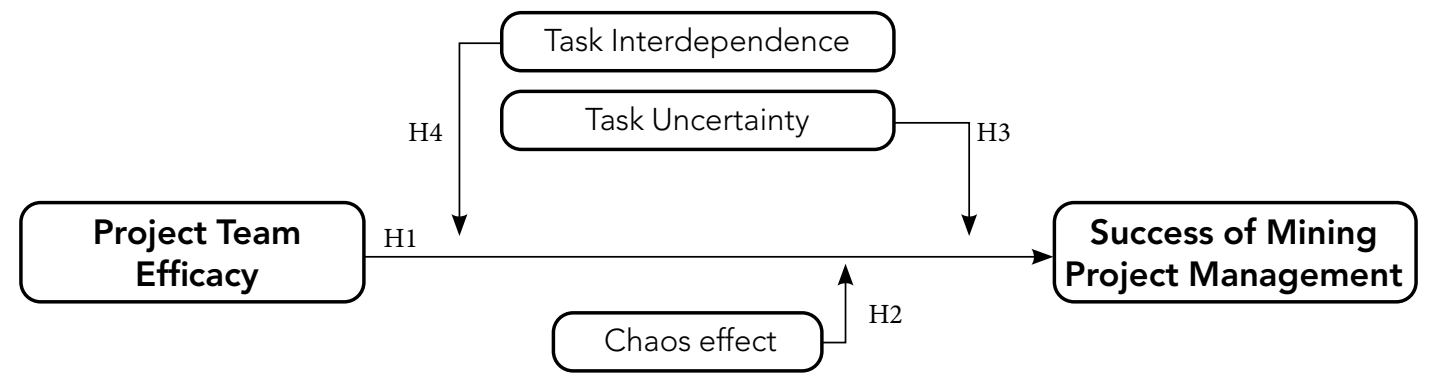

Figure 1. Theoretical model

\subsection{Study Sample and Data Collection}

The unit of analysis in this study is the project team. The study sample consisted of 52 project teams ( 520 team members), a number that represents an adequate size in accordance with Gibson (1999), Mason and Griffin (2005), and Hu and Liden (2015). The study sample project teams worked in the principal mines of Perú, located in the cities of Tacna, Arequipa, Cajamarca, Ancash, Moquegua, and Junín. For the study, we selected project teams from mining companies because they are business units that continually develop projects based on productivity, customer service, and quality, besides they have reasonably 
sized investments. According to the report of Perú's Ministry of Energy and Mines, the portfolio of investment projects for mining in Perú between the years 2012 and 2018 was predicted to reach approximately $\$ 50$ billion USD.

Each project team was composed of between ten and twelve individuals, yielding 520 valid questionnaires. Data collection was performed personally and by visiting the project teams of each mining company; the follow-up to collect the questionnaires was conducted both by e-mail and telephone. Researchers sent out 624 questionnaires and received 520, indicating a response rate of $83 \%$. The total of those surveyed included $96.4 \%$ men and $3.6 \%$ women; $65.8 \%$ married and $34.2 \%$ single. Their ages were sorted into three groups (44.4\% between 25 and 35 years old, 30.9\% between 36 and 45 years old, and $24.7 \%$ between 46 and 60 years old); $58.9 \%$ had a university level education, $33.5 \%$ had completed master's studies, and $7.6 \%$ had completed technical studies.

\subsection{Instrument of Measurement}

A questionnaire was designed with 50 questions to evaluate the seven study variables: success of project management, project team efficacy, task uncertainty, task interdependence, field independence, composition, and organizational identification. Likert-type scales were used for each of these variables, with values between 1 and 7 . For the eighth variable, chaos effect, a measurement model that uses rates between earned value and planned value or actual cost was employed.

To design the dependent variable success of project management, a group performance test was used, taking into account the items utilized by Mason and Griffin (2005). For the independent variable project team efficacy, the test of group potency and group discussion proposed by Gibson et al. (2000) was used. The two moderator variables (task uncertainty, task interdependence) were taken from Campion et al. (1993) and Hu and Liden (2015).

The process of elaborating and validating the instrument of measurement consisted of the following actions: a) translation of the original questionnaire from English to Spanish by an authorized translator, b) editing of the questionnaire by an expert in translation interpretation, c) conduction of pilot trials to confirm the reliability and validity of the instrument, and d) adjustments to the final instrument. 
For the third moderator variable, chaos effect, we used a measurement of the chaos of the indicators of project success, known as SPI and CPI. These chaos tests were obtained using graphical interface between cumulative CPI at 10-20\% complete and final CPI according to Henderson and Zwikael (2008). Values of CPI or SPI above or below 1.0 repeated times (2 times or more) in the life cycle of the project were compared with the real result at the close of each project. If the time or cost of these projects is greater than planned repeated times, the variable will be assigned a dummy value of 1 , signifying that it comes from a chaotic situation. Conversely, if the time or cost of these projects is above or below 1.0 but retains uniform behavior values, this variable will be assigned a value of 0 , signifying that it comes from a non-chaotic situation. In this way chaos effect was tagged to these projects.

Table 1 shows the results of the validity and reliability of the proposed constructs. To verify the validity of the instrument with these variables, we conducted an exploratory factorial analysis, because we were seeking relevant factors for project teams. For this reason, the validity of the construct for this investigation was convergent and discriminating because there are no theoretically linked concepts that are related to the corresponding theories (Campbell \& Russo, 2001). In other words, for our case, the exploratory factorial analysis of the correlation matrix and its results were used as an indication of convergent and discriminating validity (Batista-Foguet, Germà, \& Alonso, 2004).

We evaluated the measurement of each of the proposed variables using a factor analysis with varimax rotation : a) the success of project management was composed of nine items with the following factor loadings between 0.563 and 0.825 ; b) the project team efficacy was composed of eight items with the following factor loadings between 0.594 and 0.813 ; c) the task uncertainty was composed of three items with the following factor loadings between 0.616 and 0.751 ; d) the task interdependence was composed of six items with the following factor loadings between 0.536 and 0.848 .

To test the reliability of the study variables, we calculated the Cronbach's Alpha of each one. The statistical results for the success of the project management were 0.62; project team efficacy had a value of 0.71 ; task uncertainty, 0.76 , and task interdependence, 0.71 . In all cases, the values were higher than 0.6 , which yields a reliability level relevant to exploratory investigations (Huh, Delorme, \& Reid, 2006). 
All the variables in the study passed the Kolmogorov-Smirnov test of statistical normality with a critical p-value of 0.2 ; this value is below 0.05 ; thus, the hypothesis of normality of the sample can be accepted. Similarly, the data passed Levene's test for homoscedasticity with a critical p-value of 0.787 ; given that this value is greater than 0.05 , the hypothesis of homogeneity of variance can be accepted, showing that the variances of each study group are homogenous.

Table 1. Summary of the Statistical Analysis of the Measurements

\begin{tabular}{lcccc}
\hline \multicolumn{1}{c}{ Variables } & Mean & $\begin{array}{c}\text { Standard } \\
\text { deviation }\end{array}$ & $\begin{array}{c}\text { Factor } \\
\text { loading }\end{array}$ & $\begin{array}{c}\text { Cronbach's } \\
\text { Alpha }\end{array}$ \\
\hline Success of Mining Project Management & 4.8 & 0.7 & $0.563-0.825$ & 0.62 \\
\hline Project Team Efficacy & 4.7 & 0.8 & $0.594-0.813$ & 0.71 \\
\hline Task Uncertainty & 5.1 & 1.2 & $0.616-0.751$ & 0.76 \\
\hline Task Interdependence & 4.4 & 0.6 & $0.536-0.848$ & 0.71 \\
\hline
\end{tabular}

\section{Results}

A correlation analysis was conducted in this study, finding significant values in the study variables (table 2); in all cases, the values are below 0.9 , which shows independence of the study variables (Hair et al., 1992).

Table 2. Correlation Matrix

\begin{tabular}{|c|c|c|c|c|c|c|}
\hline & Variable & Mean & $\begin{array}{l}\text { Standard } \\
\text { deviation }\end{array}$ & 1 & 2 & 3 \\
\hline 1 & Success of Mining Project Management & 4.8 & 0.7 & & & \\
\hline 2 & Project Team Efficacy & 4.7 & 0.8 & $0.52^{\star \star}$ & & \\
\hline 3 & Task Uncertainty & 5.1 & 1.2 & $0.61^{\star *}$ & $0.42^{\star \star}$ & \\
\hline 4 & Task Interdependence & 4.4 & 0.6 & $0.52^{\star \star}$ & $0.30^{*}$ & $0.35^{\star}$ \\
\hline \multicolumn{7}{|c|}{$N=52$} \\
\hline & $+p<0.1$ & \multicolumn{5}{|c|}{ Correlation is significant at the level 0.1 (2-tailed) } \\
\hline & * $p<0.05$ & \multicolumn{5}{|c|}{ Correlation is significant at the level 0.05 (2-tailed) } \\
\hline & ** $\mathrm{p}<0.01$ & \multicolumn{5}{|c|}{ Correlation is significant at the level 0.01 (2-tailed) } \\
\hline
\end{tabular}


In addition, an analysis of multicollinearity of variables was performed, showing the tolerance values and the variance inflation factor (VIF). A tolerance greater than 0.1 (Menard, 1995) and VIF values less than 10 (Meyer, Allen, \& Gellalty, 1990) indicate a good correlation. To respond to the proposed hypotheses, a hierarchical linear regression model was generated according to the constructs of this investigation, where $\mathrm{R}^{2}$ progressively increases (table 3). A total of five steps were used for this hierarchical regression.

In the first step, the composition could significantly predict the success of project management in $56 \%$ of the $\mathrm{R}^{2}(F=19.6, t=4.78, p<0.01)$. In the second step, the chaos effect was added, increasing the prediction by $12 \%$ of the $\mathrm{R}^{2}(F=15.42, t=4.8, p<0.01)$. In the third step, moderation between efficacy and chaos were added, increasing the prediction by $1 \%$ of the $\mathrm{R}^{2}(F=18.9, t=41, p<0.01)$. In the fourth step, task interdependence was added, increasing the prediction by $1 \%$ of the $\mathrm{R}^{2}(F=24.08, t=41, p<0.01)$, yielding a total prediction of $68 \%$ of the variance of the success of project management. The significant predictors were chaos effect, task uncertainty, task interdependence, and project team efficacy.

To test the hypotheses, in the fifth step of the model, all proposed interaction variables were added, yielding an increase of $1 \%$ of the $\mathrm{R}^{2}$, which confirms its moderator effect and predicts a total of $67 \%$ of the variation in the success of project management. The interaction of task uncertainty was not statistically significant; thus, hypothesis 3 is not supported. The interactions of the chaos effect and task interdependence were significant; thus, hypotheses 2 and 4 could be supported.

To interpret the significance of the interaction of the chaos effect variable with project team efficacy, we compared the success of project management for teams with high and low chaos effects. The results indicated that in addition to supporting hypothesis 2 , the correlation between the variables of project team efficacy and the success of project management was negative and significant for teams with a high chaos effect. Thus, hypotheses 1 could be supported.

In interpreting the significance of the interaction of the task interdependence variable with project team efficacy, we compared the success of project management for project teams with high and low task interdependence. The results indicated that in addition to 
supporting hypothesis 4 , the correlation between the variables of project team efficacy and the success of project management was positive and significant for project teams with a high level of task interdependence. For all cases in which variables interacted, we used the graphical method of significant interaction (Aiken \& West, 1991).

Table 3. Multivariable Linear Regression

\begin{tabular}{|c|c|c|c|c|c|c|c|c|c|c|}
\hline \multirow[t]{2}{*}{ Variable } & \multicolumn{2}{|c|}{ Step 1} & \multicolumn{2}{|c|}{ Step 2} & \multicolumn{2}{|c|}{ Step 3} & \multicolumn{2}{|c|}{ Step 4} & \multicolumn{2}{|c|}{ Step 5} \\
\hline & b & $\mathbf{t}$ & b & $\mathbf{t}$ & b & $\mathbf{t}$ & b & $\mathbf{t}$ & b & $\mathbf{t}$ \\
\hline Project Team Efficacy ([E] & 0.25 & $2.73 * \star$ & 0.09 & 0.146 & 0.15 & 0.365 & 0.20 & $2.2^{\star}$ & -1.66 & $-2.56^{\star}$ \\
\hline Task Interdependence [TI] & 0.34 & $2.95^{\star \star}$ & -0.08 & -0.14 & -0.08 & -0.14 & -0.14 & -0.36 & 0.16 & 1.25 \\
\hline Task Uncertainty [TU] & 0.23 & $3.75^{\star \star}$ & 0.48 & 1.42 & 0.47 & 1.49 & 0.36 & $3.16^{\star \star}$ & 0.21 & $4.03^{\star *}$ \\
\hline Chaos Effect [CH] & & & -0.49 & $-4.8^{\star \star}$ & -0.51 & $-5.7^{\star \star}$ & -0.45 & $-4.9^{\star \star}$ & 0.24 & 0.44 \\
\hline $\mathrm{E} \times \mathrm{CH}$ & & & -0.10 & 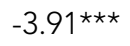 & -0.10 & -3.99 & -0.09 & $-4.01 * \star \star$ & -0.09 & $-3.74^{\star *}$ \\
\hline $\mathrm{E} \times \mathrm{TI}$ & & & & & & & & $4.55^{\star \star \star}$ & 0.06 & $5.25^{\star \star \star}$ \\
\hline ExTU & & & & & & & & & -0.39 & -1.47 \\
\hline$R^{2}$ (adjusted $R^{2}$ ) & 0.56 & $(0.53)$ & 0.68 & $(0.64)$ & 0.68 & (0.65) & 0.68 & $(0.65)$ & 0.67 & .65) \\
\hline$F$ & & 9.6 & & 5.42 & & 92 & & 1.08 & & \\
\hline $\mathrm{DR}^{2}$ & & & & 12 & & 01 & & 01 & & \\
\hline \multicolumn{11}{|l|}{$N=52$} \\
\hline \multicolumn{11}{|c|}{$+p<0.1$ Correlation is significant at the level 0.1 (2-tailed) } \\
\hline \multicolumn{11}{|c|}{ * $\mathrm{p}<0.1$ Correlation is significant at the level 0.05 (2-tailed) } \\
\hline \multicolumn{11}{|c|}{$\star * \quad p<0.1$ Correlation is significant at the level 0.01 (2-tailed) } \\
\hline
\end{tabular}

\section{Conclusions and Discussion}

Using the proposed preliminary study model, and with a representative sample of 52 teams, this investigation confirmed that a) the team, team efficacy, and task uncertainty are significant constructs that explain the success of project management and b) an elevated project team efficiency and organizational identification do not always assure the success of project management.

Meanwhile, the results confirmed that the chaos effect and task interdependence significantly moderate the relationship between project team efficiency and the success of project management (figures 2 and 3). Regarding the chaos effect, the results confirm 
that this variable negatively moderates the relationship between project team efficiency and the success of project management, which could explain why current models cannot predict the behavior of the success of project management (figure 2).

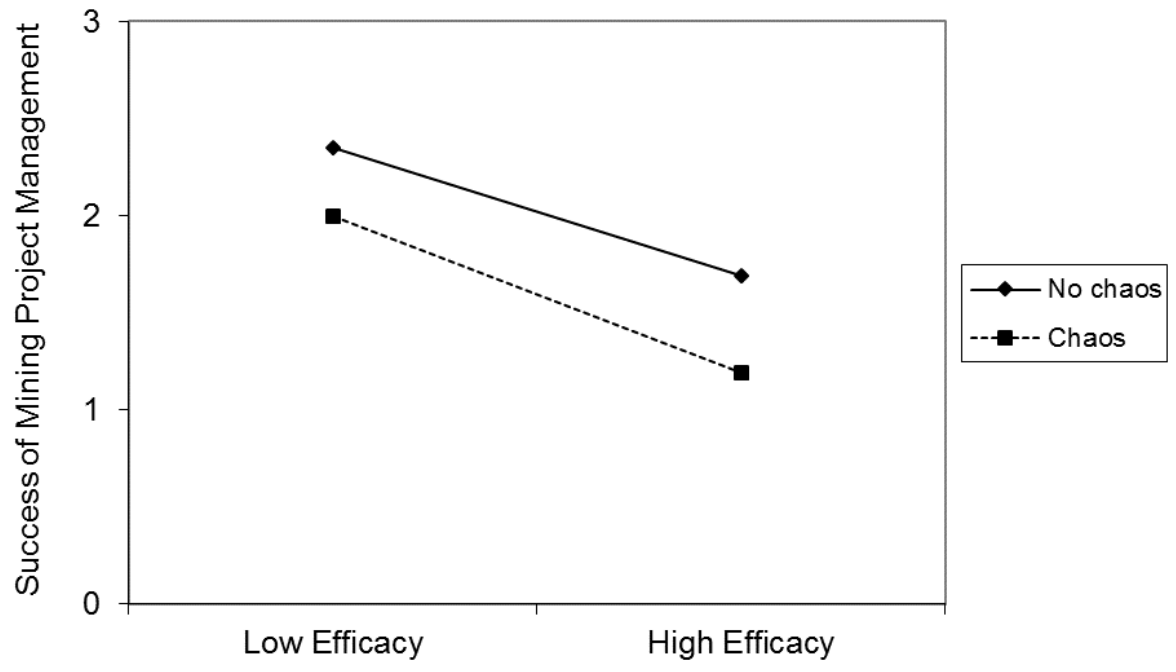

Figure 2. Project Team Efficacy with Chaos Effect

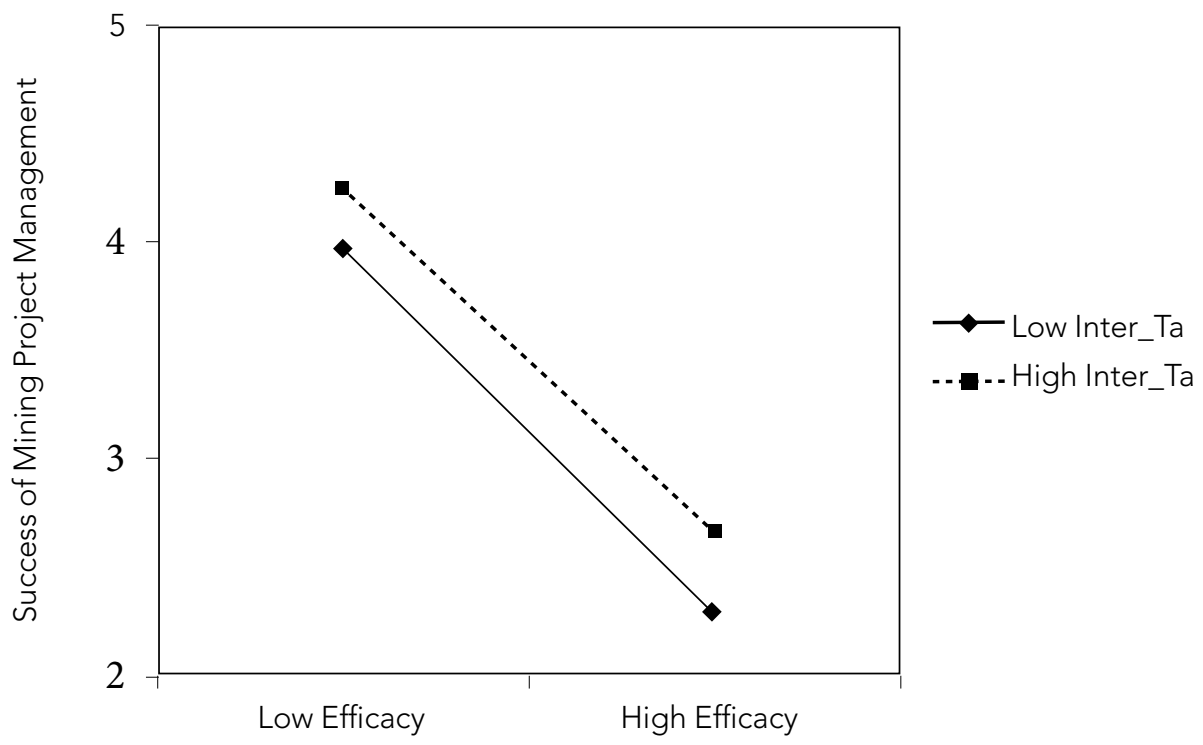

Figure 3. Project Team Efficacy with Task Interdependence 
The significant results of task interdependence could be supported by the ongoing creation of projectized structures such as work-sharing, i.e., shared, interdependent work (figure 3).

Based on the above, only hypotheses 1, 2, and 4 are supported, while hypothesis 3 is not supported by significant statistics of this new study model. In this context, an analysis of what really influences the success of projects - such as project team efficacy and the traditional factors - has been performed. This analysis provides an initial approximation using project theories and related theories, as well as epistemological parallels, as valid forms of transferring knowledge between operative and strategic organizations.

The lack of support for hypothesis 3 may be due to the ability of high efficacy groups to follow a path that they believe will lead to effective performance, but due to the inherent ambiguity of the task, their chances for actually achieving the objective are very low. This ambiguity could be understood as a new variable that, when made operative, could be related to organizational identification, a possibility that should be tested using a mediation-moderation in the variable of task uncertainty.

For these reasons, we conclude that our first research question has been answered, identifying a statistically supported relationship that is supported by previous studies in organizational theory. From this same perspective, we conclude that the concepts of chaos theory and complexity theory should be applied to project management because, as Singh and Singh (2002) noted, the application of complexity theory to management is more of a philosophical approximation and should be classified as management philosophy. Based on this, we identified the dynamic moderator variable (chaos effect), which, together with the traditional moderator variables, statistically supports the answer to our second research question, which is also supported by previous studies in organizational theory.

\section{References}

Aiken, L. S., \& West, S. G. (1991). Multiple regression n: Testing and interpreting interactions. Newbury Park: Sage Publications. 
Amoako-Gyampah, K., Meredith, J., \& White, K. (2018). Using a social capital lens to identify the mechanism of top management commitment: A case study of technology project. Project Management Journal, 49(1), 79-95. https://doi.org/10.1177/875697281804900106

Batista-Foguet, J. M., Germà, C., \& Alonso, J. (2004). Análisis factorial confirmatorio. Su utilidad en la validación de cuestionarios relacionados con la salud [Confirmatory factor analysis. Its role on the validation of health-related questionnaires]. Medicina Clinica, 122(S1), 21-27.

Blasco, J. (2001). Los proyectos, el proyectary el proyectado [Projects, projecting and the projected]. Barcelona: Edicions UPC.

Bredillet, C. N. (2008). Mapping the dynamics of the project management field: Project management in action (Part 1). Project Management Journal, 39(4), 2-4. https://doi.org/10.1002/ pmj.20091

Carpim Besteiro, E. N., de Souza Pinto, J., \& Novaski, O. (2015). Success factors in project management. Business Management Dynamics, 4(9),19-34. Retrieved from http://bmdynamics.com/issue_pdf/bmd110530a-\%2019-34.pdf

Campbell, D. T., \& Russo, M. J. (2001). Social measurement. Thousand Oaks: Sage.

Campion, M. A., Medsker, G. J., \& Higgs, A. C. (1993). Relationships between work group characteristics and effectiveness: Implications for designing effective work groups. Personnel Psychology, 46(4), 823-850. Retrieved from https://www.krannert.purdue.edu/faculty/ campionm/Relations_Between_Work.pdf

Christensen, D. S., \& Templin, C. (2002). EAC evaluation methods: Do they still work? Acquisition Review Quarterly, 105-116.

Doloi, H. K., \& Jaafari, A. (2002). Toward a dynamic simulation model for strategic decision-making in life-cycle project management. Project Management Journal, 33(4), 23-28. https://doi.org/10.1177/875697280203300404

Earley, P, G. (1993). East meets West meets Mideast: Further explorations of collectivistic and individualistic work groups. Academy of Management Journal, 36(2), 319-348. https:// doi.org/10.5465/256525

Farrel, M., \& Gallagher, R. (2015). The valuation implications of enterprise risk management maturity. Journal of Risk and Insurance, 82(3), 625-657.

Gibson, C. (1999). Do they do what they believe they can? Group efficacy and group effectiveness across tasks and cultures. Academy of Management Journal, 42(2), 138-152. https:// doi.org/10.5465/257089

Gibson, C., Randel, A., \& Earley, P. C. (2000). Understanding group efficacy: An empirical test of multiple assessment methods. Group \& Organization Management, 25(1), 67-97. https://doi.org/10.1177/1059601100251005 
Goodman, P. S., Ravlin, E. G., \& Schminke, M. (1990). Understanding groups in organizations. In L. L. Gummings \& B. M. Staw (Eds.), Leadership, participation, and group behavior (pp. 323-385). Greenwich: JAI Press.

Hair, J. F., Anderson, R. E., Tatham, R. L., \& Black, W. C. (1992). Multivariate data analysis. New York: Macmillan.

Herzog, V. L. (2001). 2000 International student paper award winner: Trust building on corporate collaborative project teams. Project Management Journal, 32(1), 28-35. https:// doi.org/10.1177/875697280103200105

Hu, J., \& Liden, R. (2015). Making a difference in the teamwork: linking team prosocial motivation to team processes and effectiveness. Academy of Management Journal, 58(4, 1102-1127. https://doi.org/10.5465/amj.2012.1142

Henderson, K., \& Zwikael, O. (2008). Does project performance stability exist? A re-exam of CPI and evaluation of SPI (t) stability? Crosstalk - The Journal of Defense Software Engineering, 21, 7-13.

Heravi, G., \& Gholami, A. (2018). The influence of project risk management maturity and organizational learning on the success of power plant construction projects. Project Management Journal, 49(5) 22-37. https://doi.org/10.1177/8756972818786661

Huh, L., DeLorme, D. E., \& Reid, L. (2006). Perceived third-person effects and consumer attitudes on preventing and banning DTC advertising. The Journal of Consumer Affairs, 4O(1), 90-116.

Jugdev, K., \& Thomas, J. (2002). Project management maturity models: The silver bullets of competitive advantage. Project Management Journal, 33(4), 4-14. https://doi. org/10.1177/875697280203300402

Kendra, K., \& Taplin, L. (2004). Project success: A cultural framework. Project Management Journal, 35(1), 30-45. https://doi.org/10.1177/875697280403500104

Khang, D. B., \& Moe, T. L. (2008). Success criteria and factors for international development projects: A life - cycle - based framework. Project Management Journal, 39(1), 72-84. https://doi.org/10.1002/pmj.20034

Lavagnon, I. (2009). Project success as a topic in project management journals. Project Management Journal, 4O(4), 6-19. https://doi.org/10.1002/pmj.20137

Liberatore, M. (2002). Project schedule uncertainty analysis using fuzzy logic. Project Management Journal, 33(4), 15-22. https://doi.org/10.1177/875697280203300403

Lindsley, D. H., Brass, D. J., \& Thomas, J. B. (1995). Efficacy- performance spirals: A multilevel perspective. Academy of Management Review, 20(3), 645-678. https://doi. org/10.2307/258790 
Loo, R. (2002). Journaling: A learning tool for project management training and team-building. Project Management Journal, 33(4), 61-66. https://doi.org/10.1177/875697280203300407

Mason, C. M., \& Griffin, M. A. (2005). Group task satisfaction: The group's shared attitude to its task and work environment. Group \& Organization Management, 30(6), 625-652. https://doi.org/10.1177/1059601104269522

Mathieu, J., Maynard, M.T., Rapp, T., \& Gilson, L. (2008). Team effectiveness 1997-2007: A review of recent advancements and a glimpse into the future. Journal of Management, 34 , 410-476. https://doi.org/10.1177/0149206308316061

Menard, S. (1995). Applied logistic regression analysis. Thousand Oaks: Sage.

McCray, G. E., Purvis, R. L., \& McCray, C. G. (2002). Project management under uncertainty: The impact of heuristics and biases. Project Management Journal, 33(1), 49-57. https:// doi.org/10.1177/875697280203300108

Meyer, J. P., Allen, N. J., \& Gellalty, I. R. (1990). Affective and continuance commitment to the organization: Evaluation of measures and analysis of concurrent and time-lagged relations. Journal of Applied Psychology, 75(6), 710-720. https://doi.org/10.1037/0021-9010.75.6.710

Olaniran, O. J, Love, P. E. D., Edwards, D., Olatunji, O. A., \& Matthews, J. (2015). Cost overruns in hydrocarbon megaprojects: A critical review and implications for research. Project Management Journal, 46(6), 126-138. https://doi.org/10.1002/pmj.21556

Parker, D., \& Stacey, R. (1996). Chaos, management and economics. Organization Studies, 17, 150-153.

Parkinson, C. N. (1957). Parkinson's law, and other studies in administration. New York: Random House.

Pennypacker, J. S., \& Grant, K. P. (2003). Project management maturity: An industry benchmark. Project Management Journal, 34(1), 4-11. https://doi.org/10.1177/875697280303400102

Pinto, J. K., \& Slevin, D. P. (1988). Project success: Definitions and measurements techniques. Project Management Journal, 19(1), 67-72.

Rakestraw, T. L. (2014). The role of performance feedback in the transfer of teamwork skills. Business Education Innovation Journal, 6(1), 41-47.

Rolfe, B., Segal, S., \& Cicmil, S. (2016). An existential hermeneutic philosophical approach to project management. Project Management Journal, 47(3), 48-62. https://doi. org/10.1177/875697281604700305

Shenhar, A., \& Dvir, D. (2007). Project management research: The challenge and opportunity. Project Management Journal, 38(2), 93-99. https://doi.org/10.1177/875697280703800210 
Shenhar, A., Dvir, D., Guth, W., Lechler, T., Panatakul, P., Poli, M., \& Stefanovic, J. (2005, August). Project strategy: The missing link. Paper presented at the Academy of Management Annual Meeting, Honolulu, HI.

Singh, H., \& Singh, A. (2002). Principles of complexity and chaos theory in project execution: A new approach to management. Cost Engineering, 44(12), 23-33.

Standish Group. (2015). CHAOS summary 2015. Boston: The Standish Group International.

Steen, J., DeFillippi, R., Sydow, J., Pryke, S., \& Michelfelder, I. (2018). Projects and networks: Understanding resource flows and governance of temporary organizations with quantitative and qualitative research methods. Project Management Journal, 49(2), 3-17. https:// doi.org/10.1177/875697281804900201

Turner, J. R., \& Müller, R. (2003). On the nature of the project as temporary organization. International Journal of Project Management, 21(1), 1-8. https://doi.org/10.1016/S02637863(02)00020-0

Wageman, R. (1995). Interdependence and group effectiveness. Administrative Science Quarterly, 4O(1), 145-180.

Westerveld, K. (2003). The project excellence model: Linking success criteria and critical success factors. International Journal of Project Management, 21(6), 411-418. https://doi. org/10.1016/S0263-7863(02)00112-6

de Witt, A. (1988). Measurement of projects success. Project Management Journal, 6(3), 164170. https://doi.org/10.1016/0263-7863(88)90043-9 